\section{転倒予防パンフレットおよびリハビ リテーション同意書の試作}

岡山大学医学部リハビリテーション部

\section{千田 益生}

\section{はじめに}

医療事故が多発している現在, リハビリテーシ ヨン（以下，リ八）医療においても例外ではな い. 各病院それぞれ，リスク管理については，リ スク管理委員会の設置, リスク管理マニュアルの 作成，インシデント・アクシデントレポートの義 務化，医療職員の認識の向上などの取り組みが行 われている。

岡山大学附属病院では, 転倒予防の観点から転 倒予防パンフレットを，またリハ中に予測される 事故防止の観点からリ八同意書を作成した。これ ら転倒予防パンフレットおよびリ八同意書を作成 し患者に配布した目的は, 転倒予防やリハ中の事 故防止に関するリスク管理には，医療サイドだけ ではなく患者に危険を認識してもらい，医療サイ ドと協力して医療事故を防止していくことが必要 と考えたからである。転倒予防パンフレットおよ びリハ同意書について報告する。

\section{転倒予防パンフレット}

病院内での転倒事故は後を絶たない. 病院内は 安全なようで, 意外と危険な場所が多い. 段差の ある廊下，めくれかけた足ふきマット，物がいっ ぱい置いてある狭い廊下, 掃除の後の濡れた廊下 など，転倒の危険性はいたるところにある。ま た, 病院には, 麻痺のある患者, 長期臥床からや つと歩行している患者, 神経疾患患者, 眠剤を服 用している患者など, 転倒しやすい要素を患者側 が持っている場合も多い．転倒は患者自身に起こ ることなので，患者自身に危険性を認識してもら った方が有効ではないかということで, 転倒予防 パンフレットを作成してみた（図1)。
まず，転倒を起こしやすい項目をピックアップ し，できるだけやさしい言葉で簡単に，絵を多く して一目でわかるように，特に高齢者をターゲッ トとして作成した. A 4 判でカラー印刷である. 1 枚のパンフレットであり, タイトルは「転んで からでは遅い」とした。 6 種類の内容に，わかり やすい絵を配し注釈を付けた。

まず 1 番目として,「スリッパやサンダルは止 めましょう」という内容である.下の注釈には, 「スリッパやサンダルは脱げやすく, 思わぬ所で つまずいたりしやすいので，ちゃんとした靴を履 きましょう」と記載した。患者の多くはスリッパ で病院内を歩いているが，スリッパが脱げやすか ったり思わぬところで引つ掛かったりする。リハ 室に来られる時にもスリッパやサンダル履きの患 者が多く，それらの方々を見るたびに担当訓練士 や患者に注意するがなかなか止めない.

2 番目は,「ベッドからの起きあがり, 夜のト イレは足元に注意して」というタイトルで，下の 注釈には，「ベッドから起き上がるとき，特に夜 間にトイレに行くときには足元に十分注意しまし ょう。枕元の明かりをつけて移動しましょう」と 記載した。この項目による転倒が最も頻度が高い ので注意が必要である。夜トイレに行こうとして 転倒ということが多く, 看護婦を必ず呼ぶように 言われている患者でも勝手にトイレに行ってしま うなど，トイレに関しての転倒は非常に多い.

3 番目には,「床が需れていないか, 段差はな いか確認して歩きましょう」という項目で，注釈 には,「床が濡れていますと滑りやすく危険です。 配膳車の周囲やトイレ，洗面所など水回りでは特 に注意しましょう」と記載した。特に気になるの は, 掃除業者の方は一生懸命されているのはわか るが，モップなど需れたもので床を拭く場合，掃 除した後は普通の我々でも滑りそうな感じがす る.

4 番目は「手すりや杖を利用しましょう」とい うタイトルで，注釈には，「廊下や階段は手すり を持って移動しましょう. 大丈夫と思っていても 寝ていますと体力は落ちています」と記載した。 患者には手すりを利用することを勧めても，廊下 


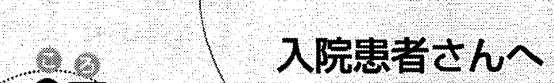

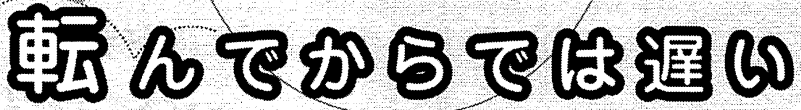

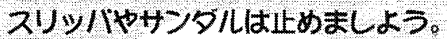

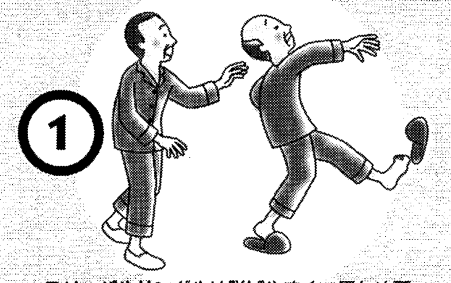

スソッパヤサンダルは脱げやすく、思わぬ兹 てつますいたりしやすいのて、ちっんとした

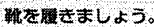

ヘットからの起きあがり、夜のトイ しは足元に注意して。
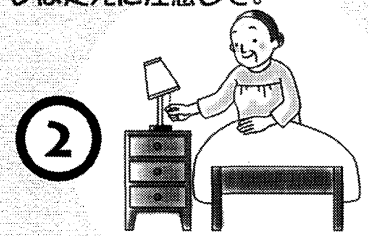

ベッドから起きあがるとき、特に夜闌にトノ しに行くときには足元に十分注意しましよう。 枕元の明かりをつけて移勤しましよう。

㦿は霹れていないが、段盖はないが 確証して步きましょう。

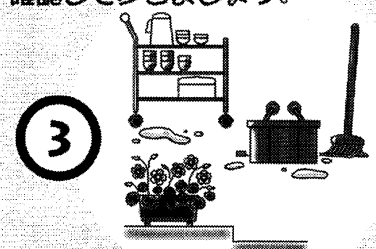

林が霜れていますと滑りやすく危険てす。配 䁃菓の周团やトイレ、洗面所など水回りでは 特に注植しましょう。

手すりや杖を利用しましよう。

院

内

て

क

$+$

転

倒

予

防

の

た

め

に

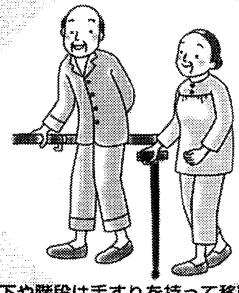

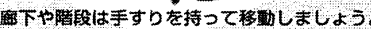
大丈夫と思っていても俍ていますと体力は落 ちています。

足元がßららつく作用がある楽を鯑ん

ていませんか。

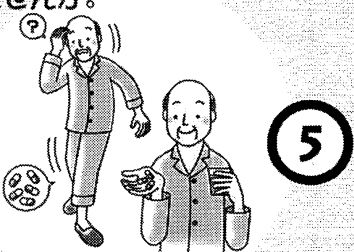

眠れないときの蔡を飲むと、体にカかスらない ことがあります。嗄る支度をすませてから飲み ましょう。また眠れないからといって勝手に福 を增やすこととは止めましょゔ。

不安な時は、主治医、看櫵境に相談。 しましょう
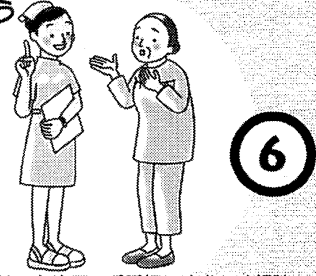

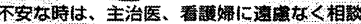
しましょう.

\section{岡山大学医学部附属病院}

図 1 転倒予防パンフレット

の手すりなどはストレッチャーや器械などが置か れていて手すりとして利用できない場面をよく見 る，廊下はできるだけすっきりと手すりを手すり として使用できるように考慮すべきである.

5 番目のタイトルは，「足元がふらつく作用が ある薬を飲んでいませんか」とした. 下の注釈に は，「眠れないときの薬を飲むと，体に力が入ら ないことがあります，寝る支度を済ませてから飲 みましょう。また眠れないからといって勝手に量
を増やすことは止めましょう」と記載した，催眠 鎮静剤などのふらつく作用のある薬剤を服用して いる場合には，服用してからトイレに行ったり， 患者自身が勝手に量を増やしたりすることがあり 危険である，服用している薬剤について，患者自 身も認識する必要がある。

6 番目のタイトルは, 「不安な時は, 主治医, 看護婦に相談しましょう」というものである，何 でも遠慮せずに気軽に相談してほしいという意味 
である(図 1).

平成 12 年 8 月から，入院患者全員に入院受付 で配布した。転倒事故は，配布前の 4 力月に 24 件であったものが，配布後 4 力月では 17 件と少 し減少した感があった。転倒予防のパンフレット を渡しただけでは，患者さんの認識を得ることは 難しい。スリッパは危ないですよとか転ばないよ うにしましょうと注意することが大切で，患者さ
んと言葉を交わすことが転倒予防には重要であ る.

\section{リハ同意書}

患者にメスを入れるわけではないが, リハを行 うということにも危険を伴う.リハ医療の対象と なる患者は，麻痺の存在，筋力低下，長期臥床， 手術直後, 高齢, 心肺機能障害など医療側が注意

\section{リハビリテーション部 説明用紙}

リハビリテーション処方

1)

2)

3)

4)

5 )

I ）リハビリテーションを行うことによる期待される効果 体の機能の向上・移動能力の改善（座位、立位、歩行） 筋力の維持・増強

関節可動域の改善・拘縮予防

日常生活動作の改善

心肺機能の改善

などがあります。原因疾患の状態により、当然ながら限界があります。

II）リハビリテーションを受けない場合

長期臥床に伴う関節拘縮、筋力低下、日常生活動作の低下など廃用性症候群と呼ばれる寝 たきり状態になる恐れがあります。また、誤った方法で行うことでかえって症状を悪化させ たり、別の症状が発生したりする恐れがあります。

\section{III）予測される合併症}

*転倒による骨折・訓練による骨折

スタッフは十分注意して訓練を行いますが、転倒の危険性は常にあります。転倒予防パン フレットなど参照されて患者さん自身も注意して下さい。また、十分に注意していても骨 が非常に弱い状態の患者さんでは、訓練中に骨折する恐れがあります。

*深部静脈血栓症

血管内に血栓ができ、他臓器（肺・脳など）に飛ぶ恐れがあります。下肢が腫れていたり、 手術後であると注意が必要です。気付いたことがあれば必ず申し出て下さい。

*心肺機能異常 (脳血管障害)

訓練を行うことで血圧の過度の上昇や不整脈、呼吸不全などを来たす恐れがあります。 訓練前の血圧測定や訓練中の状態監視など十分注意して訓練を行いますが、患者さん自身 も調子が悪いときは必ず申し出て下さい。

年旦

説明者

同意者

図 2 リ八同意書 
していても思わぬ事故が起こり得る素因を持つ場 合が多い．事故が発生した時には迅速な対応が必 要であるが，やはり予防が大切である．そのため には，患者にリハの効果，リハをしなかったらど うなるか，また起こりうる合併症などを説明して 危険性を認識してもらい, 患者自身や家族が異状 を感じた時にはスタッフに遠慮なく早期に伝える 環境を作ることが重要である，同意書には免責効 果はなく, 同意書を得ていても医療過誤があれば 当然責任は問われる。あくまでも同意書の目的 は，お互いの認識を得ることである。

リ八同意書は，まずリ八処方欄があり，その下 に，（I ）リハを行うことで期待される効果，（II） リハを受けない場合，そして，（III）予測される合 併症という順で記載した（図 2)。説明者欄には, リハ医が署名し，納得していただければ同意者欄 に患者自身がサインする。書字能力を見る上でも 有効である．患者さんがサインできない場合は， 家族にサインしてもらう．2枚綴りになってお り，1枚は患者に，1枚はリ八部で保存する。 ( I ) 期待される効果では, 体の機能の向上・移動 能力の改善, 筋力の維持増強, 日常生活動作の改 善，心肺機能の改善などを記載した．原因疾患の 状態により，限界があることも明記した。（II）リ 八を行わなかった場合では，廃用性症候群の恐れ があることを記載し，正しい方法でリハを受ける 必要があることを説明した。（III）予測される合併 症として, 転倒による骨折・訓練による骨折, 深 部静脈血栓症, 狭心症や心筋梗塞などの心肺機能 障害, 脳血管障害を記載した。「転倒予防パンフ レットなど参照されて患者さん自身も注意して下 さい」とか,「気付いたことがあれば必ず申し出 て下さい」「患者さん自身も調子が悪いときは必 ず申し出て下さい」というように患者自身に気を 付けてほしい旨を強調した（図2).

リハ同意書に対して, 患者がどのように感じて いるか無記名のアンケート調查を行った（図 3). 対象は, リ八部の初診患者 52 名である.そ の結果, リハの処方内容がわかって便利と感じた 患者は 69\%，リハの効果やしなかった場合につ いてわかるので便利は $60 \%$, 危険性について知
岡山大学リハビリテーション部 同意書に関するアンケート

現在、岡山大学附属病院リハビリテーション部ではリハビ リテーションを始める前に同意書にサインを頂いています。 同意書に関しまして、皆様のご意見を頂ければ幸いです。 ご自分の気持ちを正直にお伝え頂ければ良いと思っていま す。ご自分の気持ちに近いものがあれば○を付けて下さい。 複数付けていただいてもけっこうです。

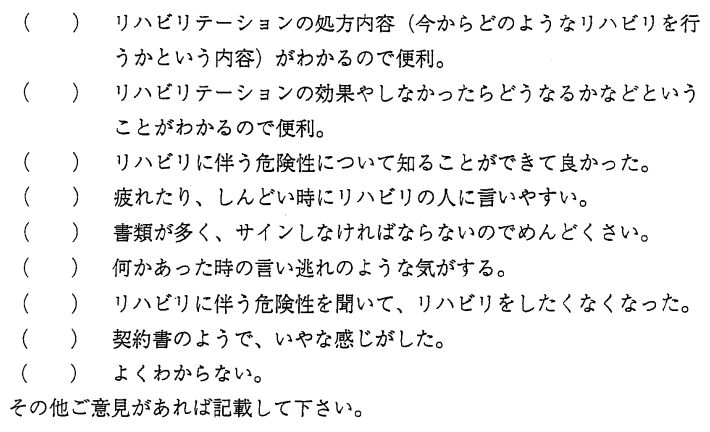

御協力ありがとうございました。今後のリハビリについて参考にさせて頂き ます。

岡山大学リハビリテーション部 千田益生

図 3 アンケート

ることができて良かったは 48\%，しんどい時に リハのスタッフに言いやすいと答えた患者さんは $50 \%$ と肯定的な意見を書いてくれた患者は 7 割以 上であった，逆に，めんどくさいが $8 \% ，$ 何かあ つた時の言い逃れのような気がするは $10 \%$ ，危 険性を聞いてリハしたくなくなったは $6 \%$ ，契約 書のようでいやな感じが $10 \%$ あった。わから ないと答えたのは，14\%であった。言い逃れのよ うな気がするや契約書のようでいやな感じという のは，同意書を作成したときに，患者はこのよう に感じるのではないかと恐れていた項目である。 医療側の保身のために同意書にサインをさせられ ると患者が感じるのも当然かもしれない. しか し, サインをすることで患者は内容をじっくり読 み理解するように努めるであろうと考えて, サイ ンをしていただいた。合併症の説明を聞いて，初 診時 3 名はリ八を受けたくないと言われ，そのう ち 2 名は 2,3 日後にやっぱりリハしたいと申し 
出があり，結局リハを行わなかったのは 1 名であ った.リハを受けないというのも患者の意思であ り尊重すべきかと思う。

\section{ま と め}

患者に危険を認識してもらい，医療サイドと協 力して医療事故を防止していくことを目的とし て，転倒予防パンフレットおよびリハ同意書を作 成した。リハ医療におけるリスク管理には患者さ んの認識・協力が大切と考える.

\section{リハビリテーション医療とリスクマ ネジメント}

産業医科大学リハビリテーション医学講座

井手 睦

\section{産業医科大学病院における現状}

産業医科大学病院は昭和 54 年に開院した総べ ッド数 600 床の特定機能病院である. 所在地の八 幡西区は人口 30 数万であり, 当院の医療圈は同 区に隣接する八幡東区，若松区，中間市，直方 市，宗像市，遠賀郡に及ぶ．産業医科大学が産業 医育成を目指して設立された目的大学であるため 産業医実務研修センターが併設されているが，い わゆる救命救急センターは有さない. 1 病棟単位 は 40 床でリハビリテーション（以下，リハ）科 は病院 5 階で泌尿器科と 20 床ずつを分け合って いる. 新設医大とはいえ開院から 20 年以上経っ ているため，正直なところ病棟の造りは車椅子を 使うリ八科患者には手狭である．回復期リ八病棟 ではないため，在院日数短縮の波をかぶり平成 13 年 3 月の平均在院日数は 42.5 日であった。病 院 1 階にあるリ八部（訓練室）はPT 5 名, OT 3 名, ST 1 名で構成されている.ここではリハ 科および他科入院患者のみでなく，地域住民を中 心にした外来リ八も実施されている，1日平均取 り扱い患者数は PT 160 件, OT 60 件, ST 15 件である。

当院では病院長を委員長とした医療事故防止委 員会の主導で近年インシデント・アクシデントレ ポートの提出が励行されている。ここでいうイン シデントは過失が発生したものの患者に危害が及 ばなかったもの，アクシデントは過失により危害 が及んだものを意味する．20床のリ八科入院患 者において看護婦または病棟主治医から提出され たレポートは，平成 12 年 1 月 1 日～12月 31 日 の 1 年間で 28 件であった。その特徴は, (1)脳血 管障害が 25 件，(2) 平均年齢が 67.1 歳，(3) 転倒 